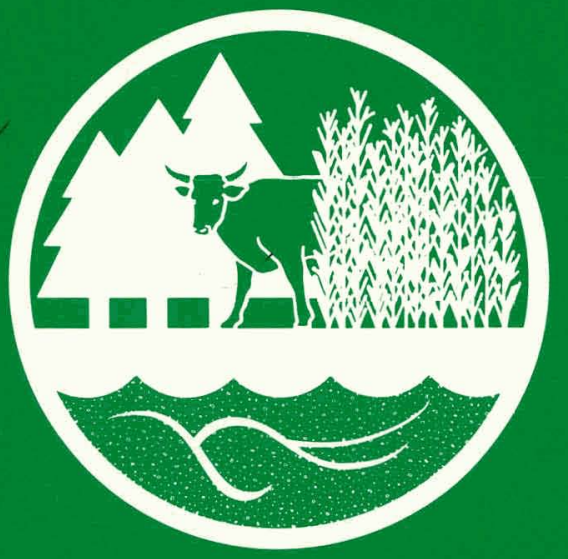

\title{
Biomass: Solar Energy from Farms and Forests
}




\section{DISCLAIMER}

This report was prepared as an account of work sponsored by an agency of the United States Government. Neither the United States Government nor any agency Thereof, nor any of their employees, makes any warranty, express or implied, or assumes any legal liability or responsibility for the accuracy, completeness, or usefulness of any information, apparatus, product, or process disclosed, or represents that its use would not infringe privately owned rights. Reference herein to any specific commercial product, process, or service by trade name, trademark, manufacturer, or otherwise does not necessarily constitute or imply its endorsement, recommendation, or favoring by the United States Government or any agency thereof. The views and opinions of authors expressed herein do not necessarily state or reflect those of the United States Government or any agency thereof. 


\section{DISCLAIMER}

Portions of this document may be illegible in electronic image products. Images are produced from the best available original document. 


\section{Biomass for Energy is:}

- Abundant

- Renewable

- Environmentally Beneficial

- Safe

- Economical

- Efficient

- Flexible

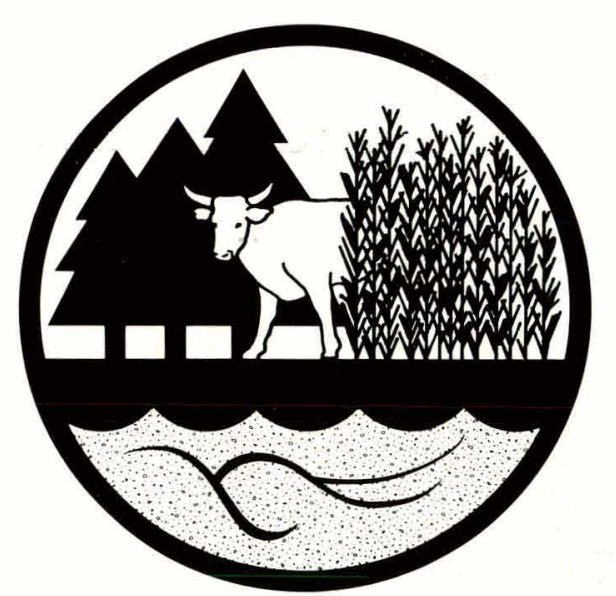

Written by

Amanda Grace, Communication Branch

Technology Commercialization Division

With technical assistance from the Market Development and

Biochemical Conversion Branches

A Technical Information Dissemination Program product 


\section{Biomass: Solar Energy from Farms and Forests}

\section{What is Biomass?}

Biomass is organic material such as trees, crops, manure, seaweed, and algae. Biomass captures and stores energy through a process called photosynthesis. This energy can be released from any form of biomass through conversion processes to produce a variety of useful energy forms-gas, steam, hydrogen, charcoal, methane, and synthetic oils with byproducts for food, fertilizers, and chemicals as a bonus. These energy forms in turn can be used to produce electricity, heal, and transportation fuels reducing the use of conventional, nonrenewable energy sources.

\section{Biomass: An Energy Source}

The use of biomass for energy is not a new idea. In the mid-1800's wood supplied over $90 \%$ of our energy needs; and, as late as $1940,20 \%$ of the homes in the United States used wood for space heating. In the past several years, homeowners have shown a renewed interest in using woodburning stoves to supplement or replace conventional space heating systems; it is estimated that in Maine alone about $40 \%$ of the homes use woodstoves.

Today, several industries and utilities are using biomass to supply about 1.4 quads of energy a year for electricity, process heat, and space conditioning. Since the total national consumption of all forms of energy resources is 75 quads, this means biomass already provides almost $2 \%$ of the U.S. needs.

The use of biomass holds much promise for the future. The world now produces billions of tons of biomass each year. Although not all of this resource can be used for energy production, enough may be available to supply several additional quads of the nation's energy yearly by the end of this century. The great diversity of sources, conversion processes, and end products makes biomass a highly flexible energy option for industry, agriculture, utilities, and the homeowner.

\section{Quad = Quadrillion Btu. One quad of energy is equivalent to enough energy to heat 500,000 homes for 20 years.}

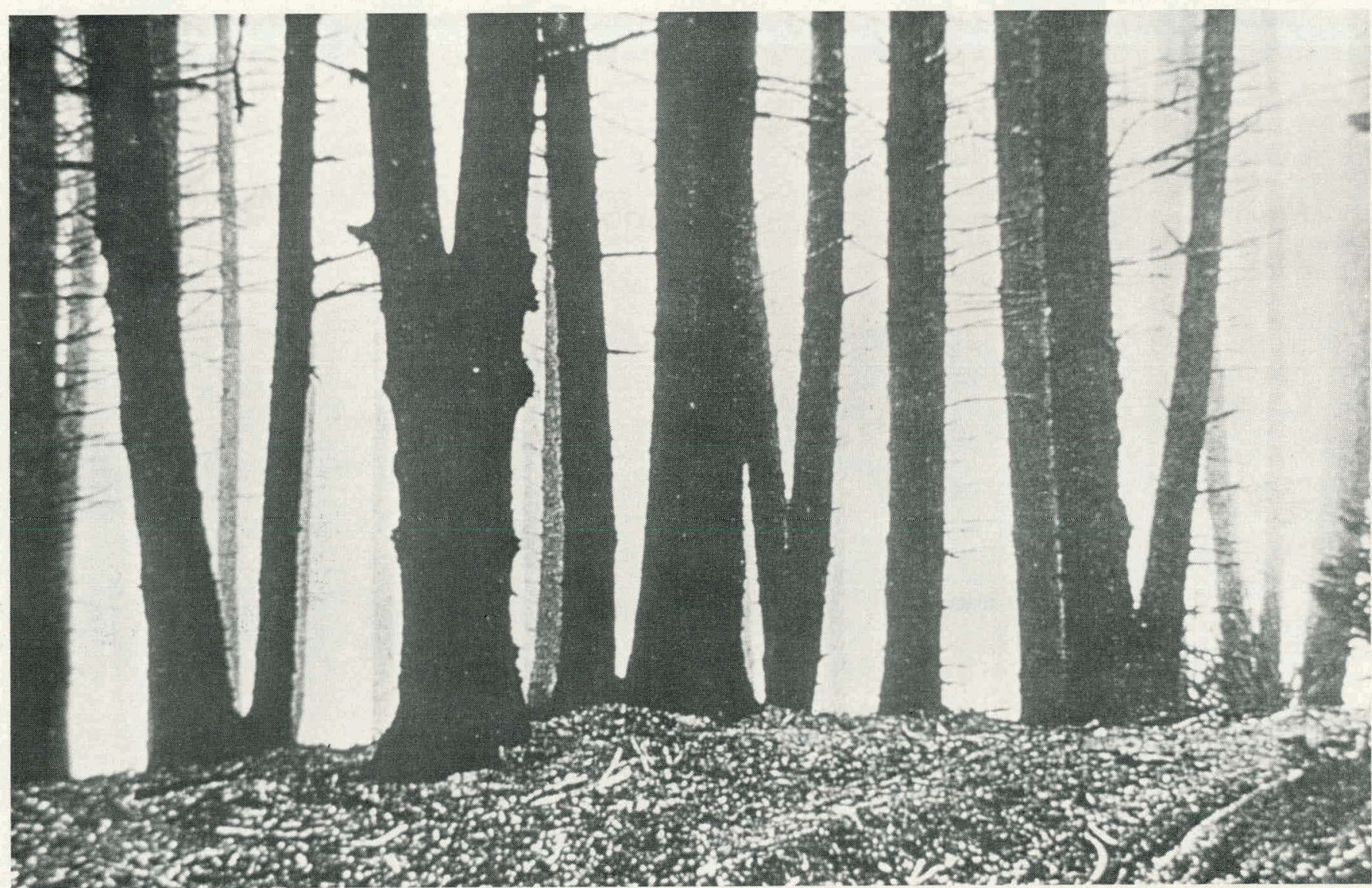




\section{Farms and Forests: Today's Energy Resource}

Everyday a valuable resource is thrown away. The forest products industry, the agricultural and food processing industries, and municipalities dispose of tons of biomass that could be used to produce energy. Most biomass now available for energy is material left over from other processes and falls into one or two categories:

- Wastes

- Rosiducs

\section{Biomass is considered a} solar-related energy source because all organic matter depends on sunlight and the photosynthetic process.
Wastes are byproducts of various manufacturing processes. For instance, wood shavings and scrap from making furniture are wastes. They are produced mostly by the forest products industry, agricultural processes, and municipalities. Other examples of wastes are:

\section{Forest}

Products

Sawdust

Bark

Paper pulp

Wood shavings

Scrap lumber

Wood dust

Papé

Agricultural \& Food Processing

Fruit pits

Walnut shells

Rice hulls

Corn cobs

Manures

Sugarcane bagasse

Municipal

Sewage

Solid wastes

Btu - British thermal unit is a measure of heat energy. One Btu is the amount of energy required to raise the temperature of one pound (about 1 pint) of water one degree Fahrenheit ( $\left.1^{\circ} \mathrm{F}\right)$. This about equals the heat from one kitchen match.

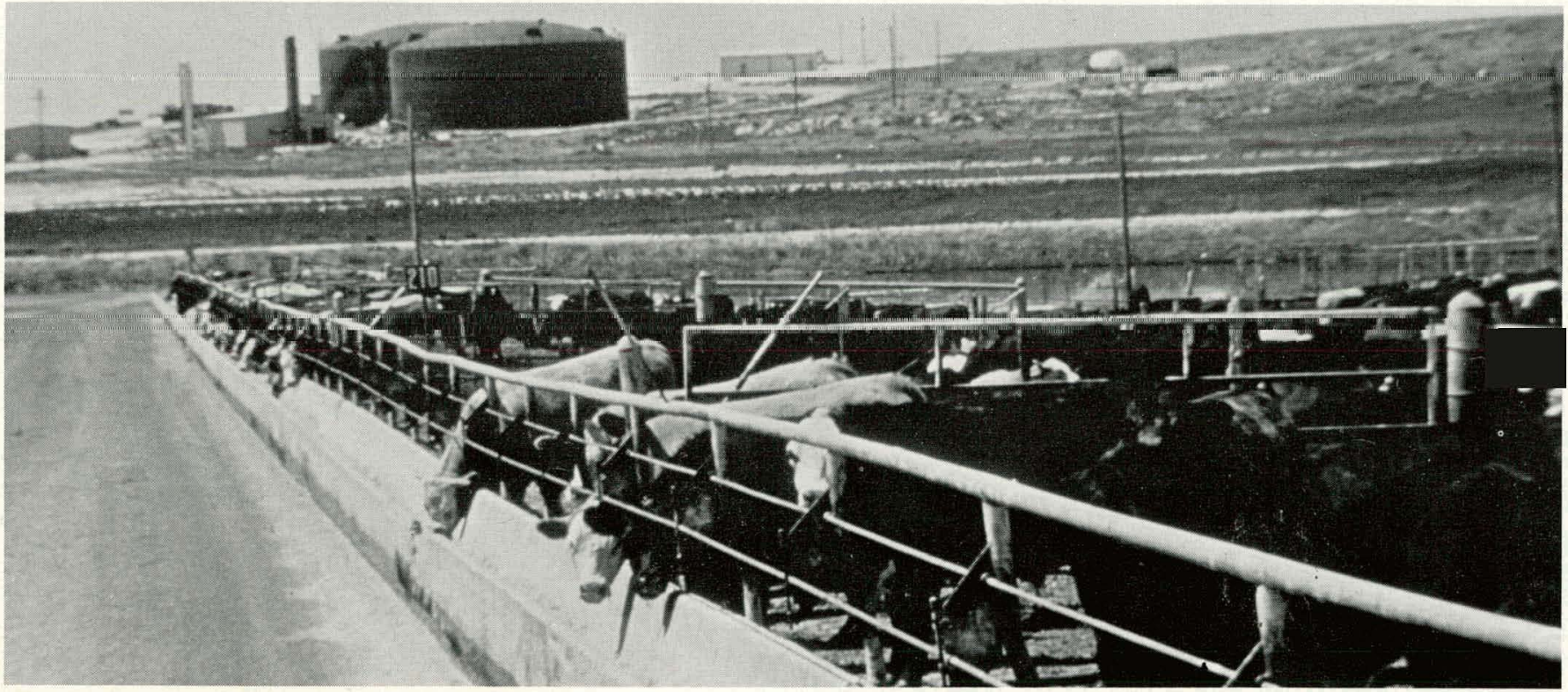

Feedlots are one source of wastes. 


\section{Taking the Energy Out of Biomass-The Conversion Process}

Fortunately, a wide variety of methods can be used to convert available biomass wastes and residues into energy. Conversion techniques range from relatively simple to quite complex. Basically, there are two types of biomass energy (bioenergy) conversion processes:

- Thermochemical conversion

- Biological conversion

\section{Thermochemical Conversion}

The thermochemical conversion process uses heat (sometimes in the absence of air) to produce chemical reactions in biomass. Examples of such conversions include:

- Direct Combustion

- Gasification

- Pyrolysis

\section{Direct Combustion}

This is the simplest and best developed biomass conversion process. Forest and agricultural wastes and residues can be burned to produce steam, electricity, or heat.

Wood and lumbermill wastes have been used successfully in boilers for process steam and electricity production for some time. It has been estimated that the forest products industry uses biomass to supply at least 1.1 quads, or about $45 \%$, of its total energy needs per year. This industry has the potential to become virtually energy self-sufficient by using more of the biomass already available to it.

Other industries, such as textiles and paper products, that require heat in the preparation and treatment process of goods can also use the direct combustion conversion process. Hot water, steam, and hot air are required for many manufacturing processes; and a large percentage of this energy could be supplied by direct combustion.

Another use of direct combustion is in woodburning stoves. Woodstoves can meet all or part of the heating needs in a carefully designed and well-insulated building.

\section{Gasification}

Gasification is another bioenergy conversion process. This process releases bioenergy by heating wastes in limited amounts of air or oxygen. Forest wastes and wastes from food processing operations can be converted hy this process. Gasification can produce synthetic natural gas (SNG), methanol, ammonia, hydrogen, carbon monoxide, or synthetic gasoline.

Sawmills and wood products manufacturing plants can use their wastes to generate gas for use in natural gुas-fired kilns and for electricity generation.
Wastes such as corn cobs, fruit pits, walnut shells, and rice hulls can also be used to produce lowor medium-Btu gas. Normally, wastes create disposal problems; but, if used in the gasification process, wastes can be converted to a valuable energy resource for the food products industry. Also, some agricultural processing facilities such as cotton gins and feed processing plants produce wastes than can be gasified.

\section{Pyrolysis}

The pyrolysis process also breaks down biomass with heat but in the absence of oxygen and at a lower temperature than is required for gasification. The biomass resources used in this process include manure, agricultural and wood wastes, papermill wastes, and municipal solid wastes. Pyrolysis yields oil, charcoal, and synthetic gas.

Industries that produce biomass wastes can use the pyrolysis process. In addition, pyrolysis may be a good method of converting municipal solid wastes (after removal of inorganic materials) to usable fuels.

\section{Cogeneration}

Cogeneration is not a biomass conversion process, but a way of using a conversion process to simultaneously produce electricity and process heat. For example, a suyar processing plant can use its own wastes to produce both electricity to operate plant machinery and steam for various heating and evaporating processes. Industrial use of cogeneration can reduce fossil fuel requirements and provide significant cost savings for the user.

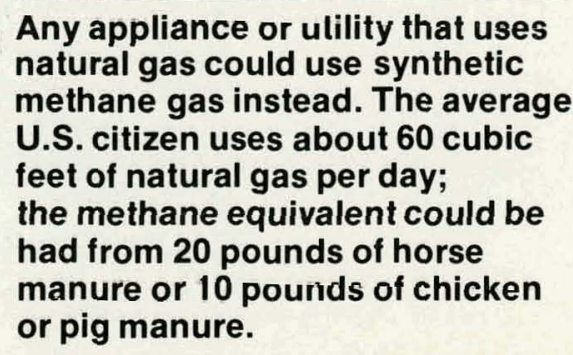




\section{Biological Conversion}

Biological conversion (bio-

conversion) is a chemical reaction caused by treating biomass with enzymes, tungi, or micro-organisms. These conversion techniques produce either liquid or solid fuels. Two processes are used today:

- Anaerobic Digestion

- Fermentation

\section{One quad of energy is equivalent to enough crude oil to fill 75 325,000-ton supertankers, each with a capacity of 2.3 million barrels.}

\section{Anaerobic Digestion}

This bioconversion process is the controlled decay of organic material in the absence of oxygen. Manures, agricultural wastes, sewage, paper, seaweed, and algae all can be converted to produce methane gas.

Sewage treatment plants have used anaerobic digestion for many years to generate methane gas. With natural gas prices on the rise, large-scale anaerobic digesters at sewage treatment plants will become more erronomically attractive in some urban arcas.

Since World War II, small-scale digesters have been used on farms, primarily in Europe and Asia. Recent estimates indicate that thousands of small biogas facilities in Korea and perhaps onehalf million units in China are used today. Many U.S. farms have biomass available and could use small-scale digesters to supply valuable onsite energy.

\section{Fermentation}

This is a well-established process in which carbohydrates (such as suyda in the form of sugar cane juice, molasses, and other cellulosic materials) are fermented and distilled to produce ethyl alcohol (ethanol).

A mixlure of $10 \%$ ethanol and $90 \%$ gasoline (known as gasohol) is usable in any internal combustion engine without modification to the carburetor. The gasohol now being widely userd is made primarily from grain in cunventinnal distilleries, using methods nriginally developed for bevcrage alcohols. This use of biomass could lessen our dependence on imported oil.

\section{A pound of dry plant tissue, when simply harvested and burned, can produce 7,500 to 9,500 Btu of heat.}

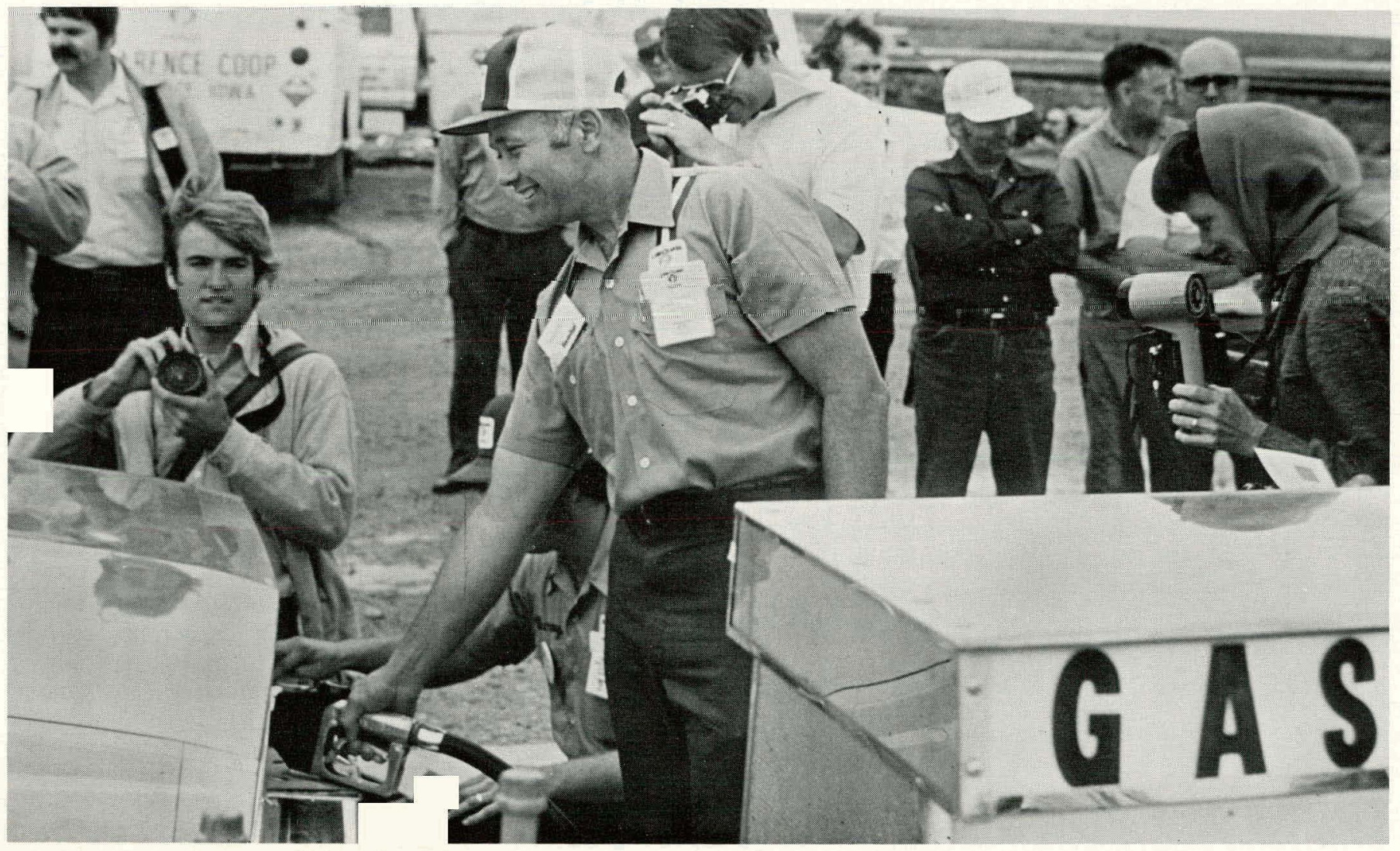

Gasohol being sold in the Midwest. 


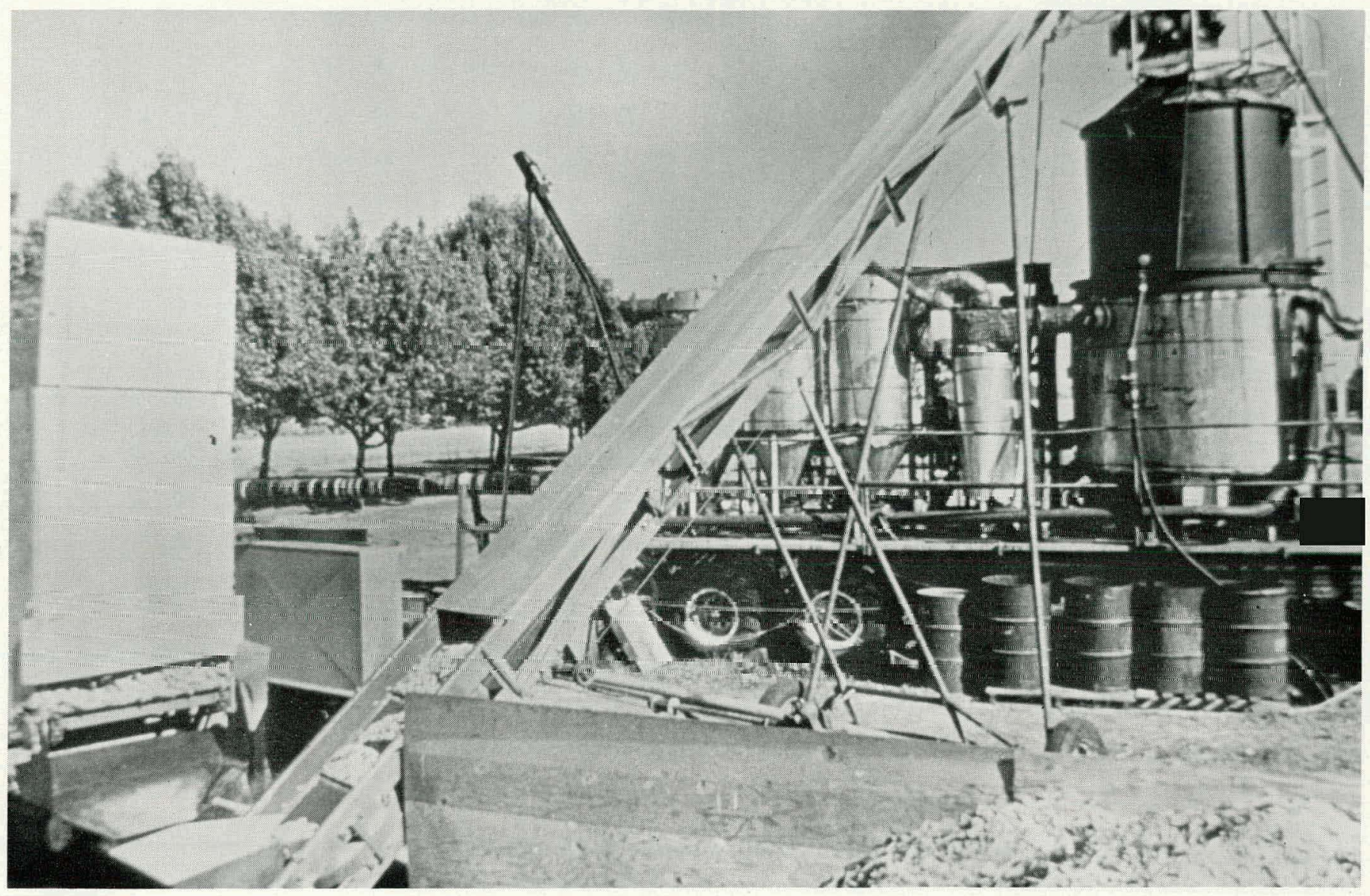

A gasification system.

\begin{tabular}{|c|c|c|c|}
\hline Energy Consumer & Energy Product & $\begin{array}{c}\text { Example of } \\
\text { Resources Used }\end{array}$ & $\begin{array}{c}\text { Example of } \\
\text { Conversion } \\
\text { Process }\end{array}$ \\
\hline $\begin{array}{l}\text { Paper and Lumher } \\
\text { Companies }\end{array}$ & $\begin{array}{l}\text { Steam, Electricity, } \\
\text { Heat }\end{array}$ & $\begin{array}{l}\text { Forest residues, } \\
\text { slash, sawdust, } \\
\text { bark }\end{array}$ & $\begin{array}{l}\text { Direct combustion, } \\
\text { Gasifiratinn, } \\
\text { Pyrolysis }\end{array}$ \\
\hline Municipalities & $\begin{array}{l}\text { Electric power } \\
\text { and gas }\end{array}$ & $\begin{array}{l}\text { Wood wastes, } \\
\text { sewage, solid } \\
\text { municipal waste }\end{array}$ & $\begin{array}{l}\text { Anaerobic digestion, } \\
\text { Gasification }\end{array}$ \\
\hline $\begin{array}{l}\text { Homeowners, Space } \\
\text { Heating Users }\end{array}$ & Heat & $\begin{array}{l}\text { Wood, biomass } \\
\text { residues }\end{array}$ & $\begin{array}{l}\text { Direct combustion } \\
\text { in wood stoves }\end{array}$ \\
\hline Cars, Trucks & Gasohol & $\begin{array}{l}\text { Agricultural } \\
\text { surplus }\end{array}$ & Fermentation \\
\hline Utilities & $\begin{array}{l}\text { Electricity, } \\
\text { Steam, Heat }\end{array}$ & $\begin{array}{l}\text { Forest and agricul- } \\
\text { tural wastes and } \\
\text { residues }\end{array}$ & Direct combustion \\
\hline
\end{tabular}




\section{Biomass At Work Today}

Although bioenergy is mainly used by the forest products industry to provide steam, there is no reason why its use has to be limited to this industrial application. Manufacturers, homeowners, utilities, and food processors are showing an increasing interest in biomass as an energy source, and they all have the capacity to increase their use of this resource. Bioenergy is technically and economically ready today for numerous applications. The following facilities are examples of biomass conversion processes at work. *

\section{Manufacturer}

A company in Sheboygan, Wisconsin, that produces and distributes wooden parts for the automotive, toy, and furniture industries has a 91,000 square foot manufacturing plant and warehouse heated by burning surplus material. Particleboard and hardwood scraps are burned in a recently developed incinerator that uses the pyrolysis conversion process.

Pyrolytic conversion takes place in two distinct steps. First, a mechanical loader feeds residue material into a pyrolysis chamber where gasification takes place Combustible gases in the chamber pass to a thermal reactor where they are ignited and completely burned. The resulting hot gases are then passed through a boiler where heat is given up to produce steam for the plant's heating system.

The sysilem's capital costs totaled $\$ 100,000$, and initial indications are that it will pay for itself within 2 years. The company will save $\$ 18,000$ each year on scrap disposal and $\$ 45,000$ annually by not having to buy fuel.

* Taken from U.S. Department of Energy, "Biomass Energy Success Stories-A Portfolio Illustrating Current Economic Uses of Renewable Biomass Energy," HCP/T0285-01, March 1978.

\section{Residence}

A 1,600 square foot home in northern Minnesota is heated entirely by a small airtight woout stove burning a mixture of birch and aspen logs. Careful design allows heat to be distributed throughout the house without using ductwork or fans. The system has performed well over several winters, maintaining average temperatures of $70^{\circ}$ to $75^{\circ} \mathrm{F}$ throughout the house. Energy conservation measures were taken to increase the efficiency of the woodstove.

The heating system's cost was extremely low-\$bu for structural reinforcement around the air circulation holes and less than $\$ 200$ for the woodstove. Four cords of mixed aspen and birch (at \$23 per cord) are required annually to heat the house and an adjacent shop.

\section{Utility}

The city of Eugene, Oregon, with a population of 175,000 , owns water, steam, and electric power utilities. Electric power is supplied hy three hydroelectric plants of 128 megawatt total capacity, plus a steam-eler.tric plant generating 33.8 megawatts. This latter plant is fueled with surplus forest residues from the surrounding area. The plant also supplies steam heat servico to a business district, a large hospital, a college campus, a large cannery, and a 16 -acre greenhouse complex, all located within a 2 -square mile area.

Assembled hetween 1931 and 1951, the power plant houses three boilers with a combined steam generating capacity of 450,000 lb/hr. The wood residues, mostly bark, are delivered by truck to an outdoor storage pile from nearby wood products mills. Under normal conditions, the utility is operated year-round. During 8 months of the year, the balance of the steam capacity is used to generate electric power; the plant is on standby for electric power for the remaining 4 months.

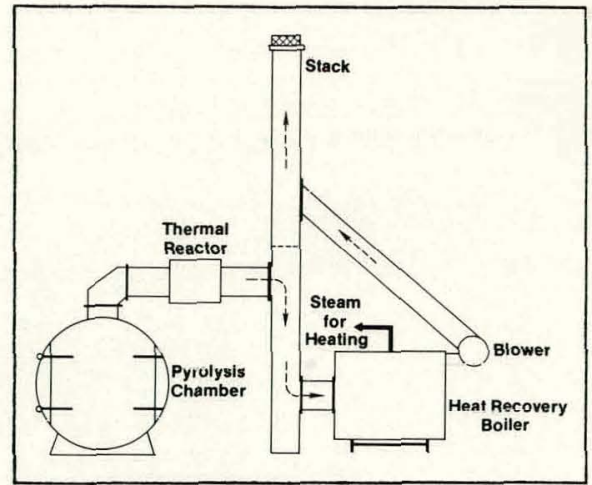

Pyrolytic Incinerator with heat recovery boiler.

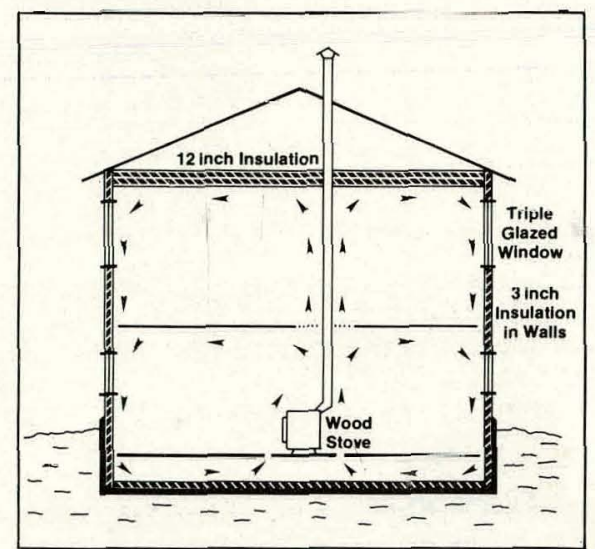

Illustration of heat distrihution by natural convection in a Minnesota house heated with a woodburning stove.

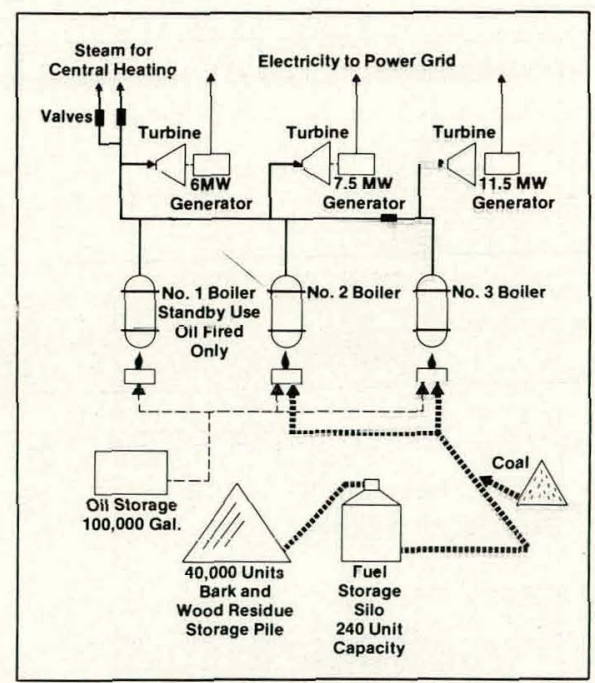

Simplified diagram for the Eugene Water and Electric Board heating and electric utility. 
By using surplus forest residues for fuel, there has been a substantial savings over using oil. The operation of the plant has proven very successful from a utility standpoint. At the same time, it reduces air pollution and contributes to the solution of wood residue disposal problems in the Eugene area.

\section{Agricultural Processing Plant}

An Oahu, Hawaii, sugar company produces energy from sugarcane wastes to cogenerate low-pressure steam and electricity. The steam is used in various heating and evaporating processes in the sugar mill, and the electricity is used to operate plant machinery and drive large irrigation pumps. Internally generated electricity accounts for $75 \%$ of the electric power consumed annually by the mill.

The sugarcane is cleaned and pressed to extract its juices and the remaining fiber (bagasse) is conveyed to the power plant where it is used to fire steam boilers for the cogeneration process.

Based on a cost of 3 cents per kWh for purchased electricity, the value of bagasse burned would amount to $\$ 3.6$ million annually. These costs can be expected to remain relatively stable compared to the rapidly escalating cost of petroleum-derived electricity in Hawaii. The energy from bagasse has helped the sugar indistry in Hawaii to survive despite depressed sugar prices and rising petroleum costs.
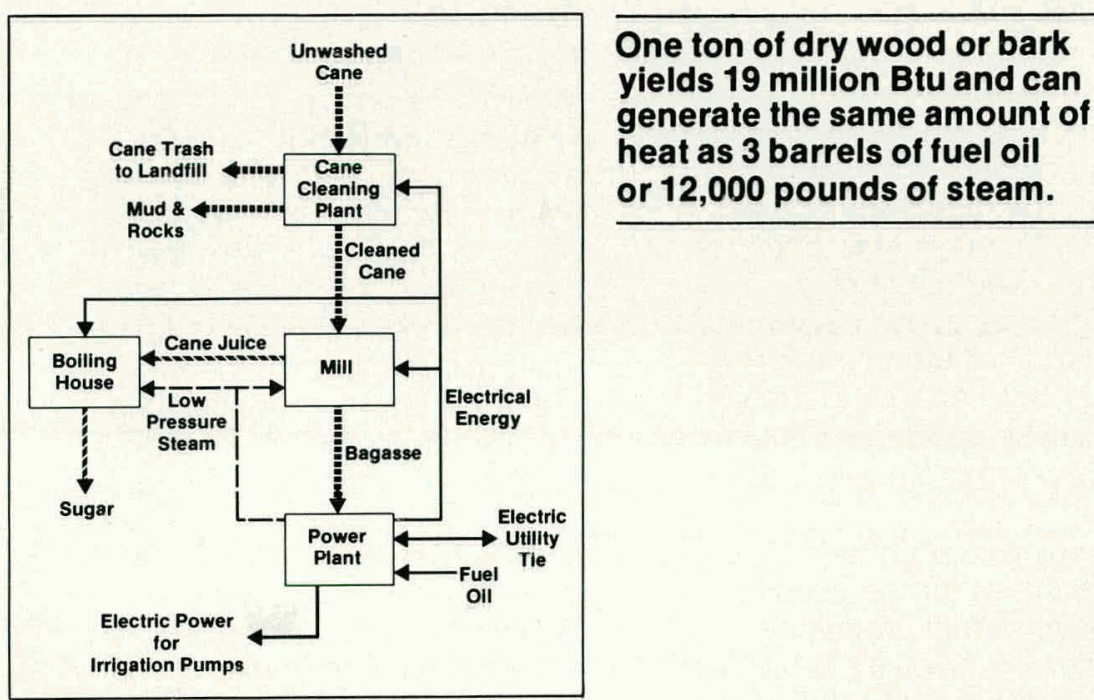

Flow of material and energy at the
Oahu Sugar Company.

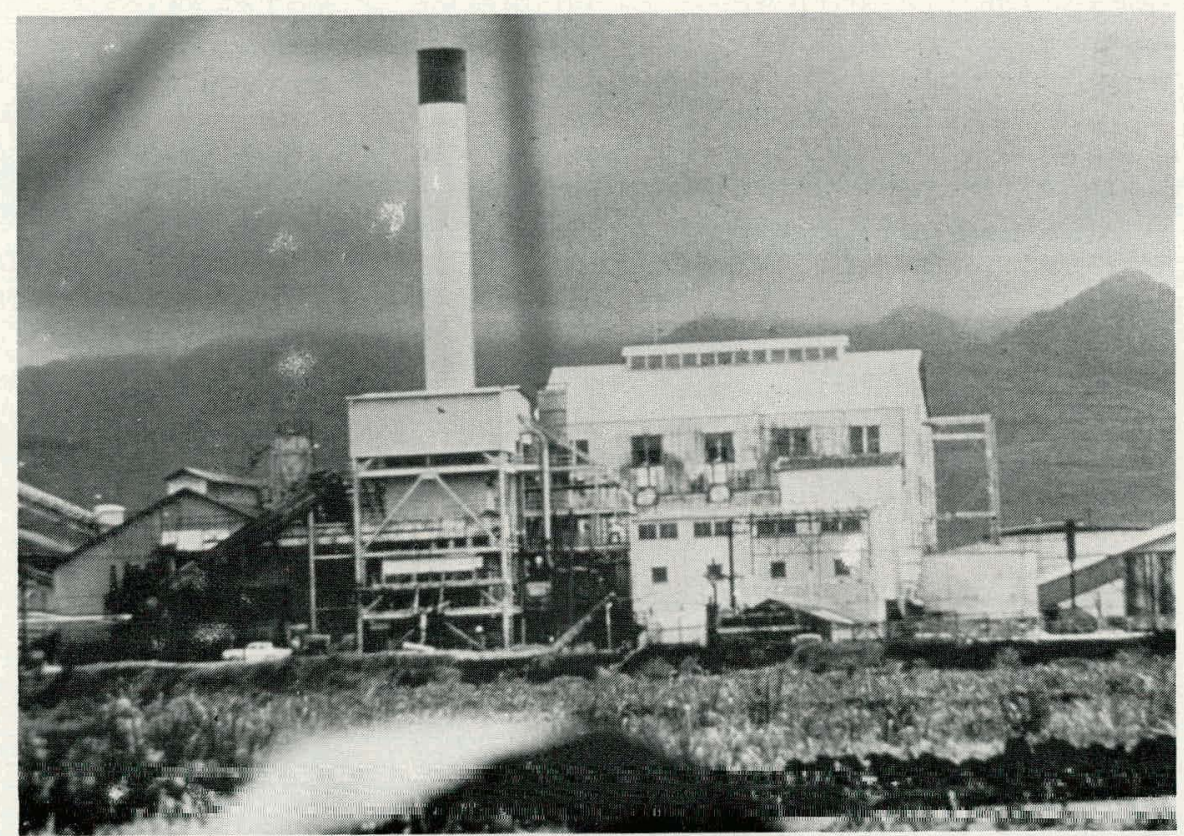

The Oahu Sugar Company, Ltd., Waipahu, Oahu, Hawail, uses wastes to produce energy. 


\section{For the Future}

\section{Growing Our Fuel}

Biomass wastes and residues are abundant today, but there is a need to investigate methods of renewing biomass resources for the future. The concept of growing crops specifically cultivated for their high energy yield per acre and short growth cycles is being explored. Four types of energy farms are presently being studied:

- The cultivation of trees (silviculture) for the specific purpose of fuel production. These farms would contain trees which grow quickly and are planted In closely spaced rows. The time from planting to harvest would be about 4 to 7 years.

- Agricultural energy farms to cultivate crops such as corn, wheat, sugarcane, and grasses for conversion to fuels.

- Fresh water energy farms to grow various algae, duckweed, and water hyacinth for their fuel value.

- Marine energy farms to produce food, fucl, and material for binenergy conversinn processess The development of certain marine plants, such as the giant California kelp, is being studied intonsivcly.

\section{Gasohol}

Gasohol is probably the most familiar "clean fuel from biomass." Although methanol ( known as "wood alcohol," and carrying warnings against drinking) and ethanol ("grain alcohol," the beverage alcohol) were widely used for fuels in the last century, low-cost oil relegated them to premium uses such as cooking (familiar as Sterno or for fondue pots) and on the auto race track where high performance is more critical than cost.

Now that oil costs are rising, we may turn back to these clean tuels. Ethanol from grain starch and sugars now costs about $\$ 1.20$ per gallon (bulk), and methannl from wood or residues is estimated to cost from $\$ 0.50$ to $\$ 1.35$ per gallon, depending on the size of the plant and cost of the material used for the conversion process. Since the alcohols have never been produced as fuels, these prices can be expected to drop as production increases and the technology is improved.

\section{But-}

Biofucls can only become more widely used as they become more competitive with conventional energy sources. This competitiveness includes not only the costs connected with transportation and the conversion process but also issues involving resource availability and alternative uses for the resources (such as fertilizers and animal feeds). Some of these issues are:

- Although data are limited on the economics of all biomass conversion processes, enough is known so that several biomass applications are now competitive with conventional energy sources. Direct combustion and gasification (in some applications) are two such processes. The costs of these are comparable to or less than the costs of some conventional fuels in many uses.

- Further research must be done before extensive use of some biomass conversion technologies is achieved.

- As with any energy option, environmental effocts must bc carefully investigated to ensure the intelligenl use and management of the biomass resource. Overuse of this resource could affect its future availability and have a detrimental effect on the quality of our soil, air, and waler.

- Finally, new technologies sometimes require changes in attitude and conventional practices. Present industrial fuel users may be comfortable with the convenience of conventional fuels everi with recent price increases. These factors may keep them from thoroughly investigating other sources of renewable energy such as biomass 

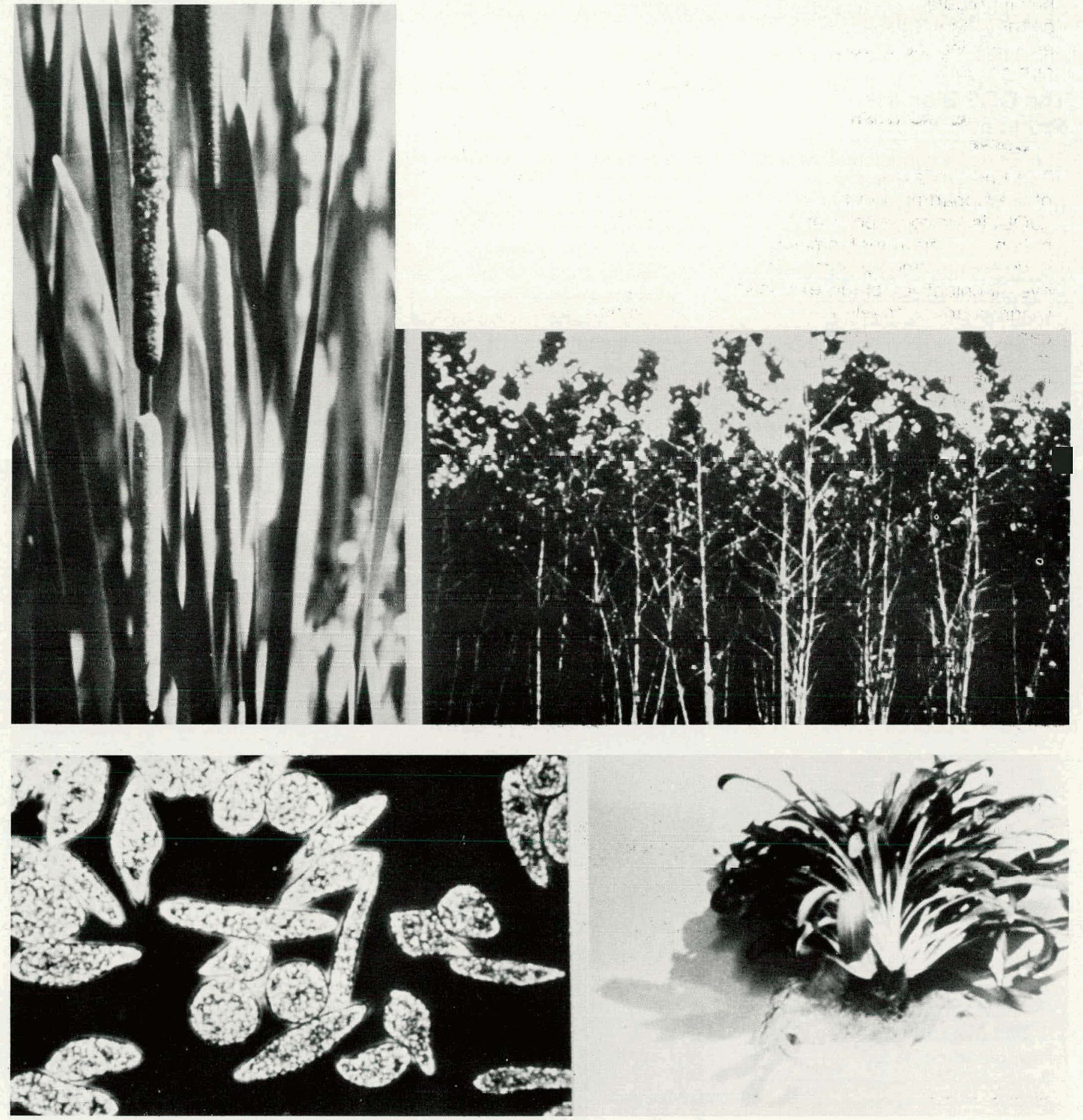

These and other land and fresh water plants can be cultivated specifically for their high energy yield per acre.

Photn credit: Binenergy Counçil 


\section{Progress Through Research}

Though problems exist, many conversion processes are used successfully now. To remove the conditions presently limiting the use of other conversion processes, various public and private organizations are conducting research in and encouraging the development of biomass.

\section{The DOE Biomass Program}

The Energy Technology Division of the Department of Energy (UUE) is the tocal point of a national program for biomass development and research. The overall objectives of this extensive program are to develop capabilities for converting renewable biomass resources into clean fuels, petrochemical substitutes, and other energy related products that can supplement products made from conventional fossil fuels. Activities are directed toward the production of biomass and the connver.sinn of hinmass into useful eneray forms. The objectives of this division will be achieved when a sound biomass industry is established.

DOE's Conservation and Solar Applications Division also has major interests in developing biomass, particularly this country's wood resource. This division has the responsibility for near-term commercialization of wood as an energy source. A Wood Resource Manager has been appointed at DOE to provide a tocus for federal activities in this area.

\section{A 2,500 square foot home in Washington, D.C., built before 1970 uses approximately $177,000,000$ Btu a year for heating and cooling.}

\section{The Biomass Program at SERI}

Support to the DOE program is being provided by the Solar Energy Research Institute (SERI) in Golden, Colorado. The SERI Biomass Program seeks to enhance research and development programs at DOE through current and planned activities in the following areas:

- System studies to identify opportunities to produce energy and energy saving chemicals from biomass

- Thermochemical conversion processes

- Biochemical conversion processes

- Research and development in photoconversion and other advanced concepts

- Fconomic and environmental assessments

- Commercialization assistance

- Biomass education

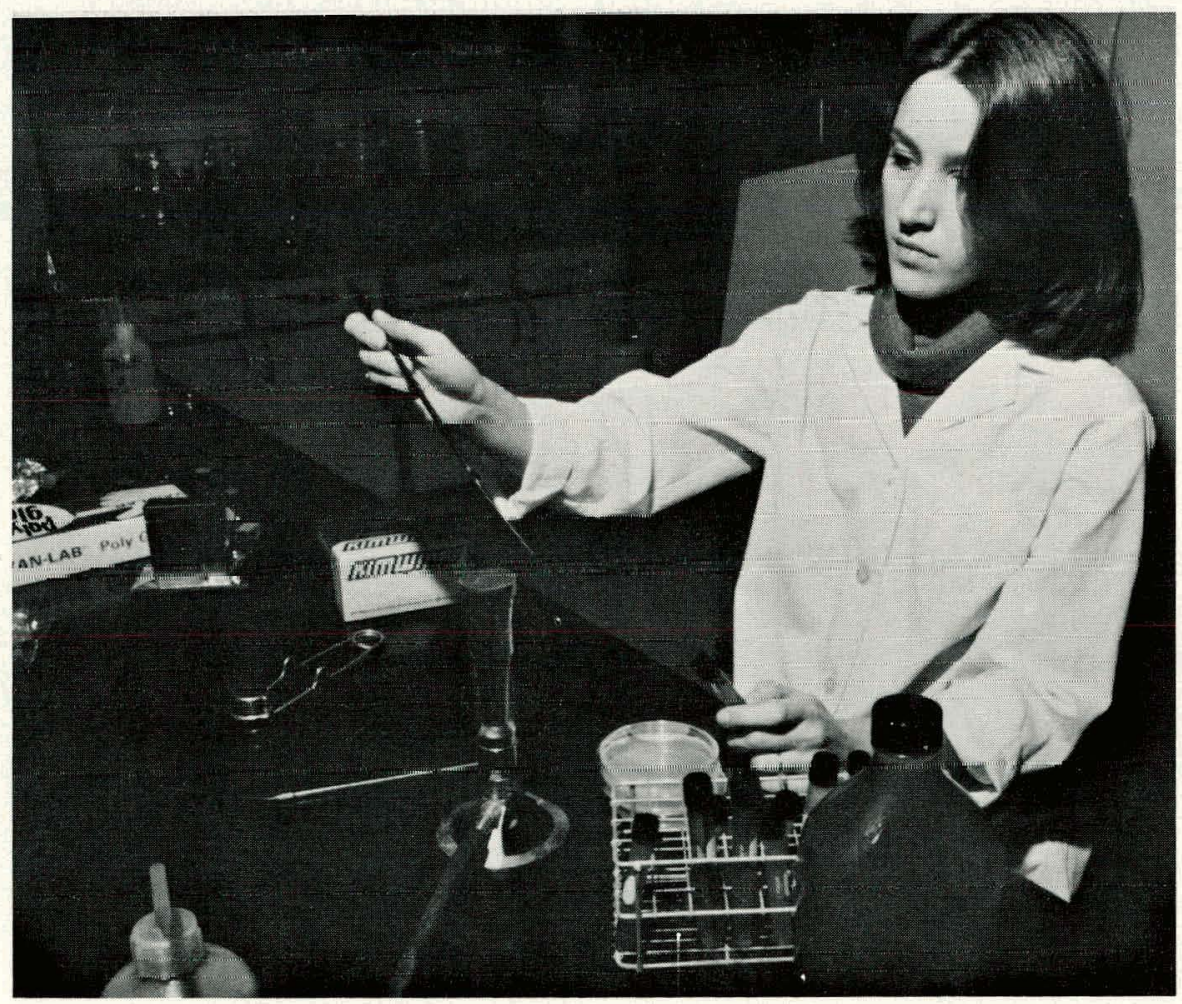

Rescarch is being done at SERI, Golden, Colorado. 


\section{Benefits from Biomass}

Although certain technical and institutional conditions are limiting the extensive use of some biomass conversion processes, other processes are ready to use now. Whatever the stage of development, using biomass offers us many benefits. Among these are:

- There is a great deal of biomass, both in terms of current wastes and potential energy crops.
- It is a renewable and nondepleting resource if properly managed.

- Some uses of residues and wastes could lessen environmental problems. Wood wastes, garbage, and agricultural residues are frequently burned or used in landfills; they could instead be used to produce energy with an environmental benefit. Using logging residues to produce energy can also reduce fire hazard, tree disease, and insect infestation.

\section{A quad is equal to the amount of energy available from 500,000 railroad} cars full of coal (based on 83 tons per car).

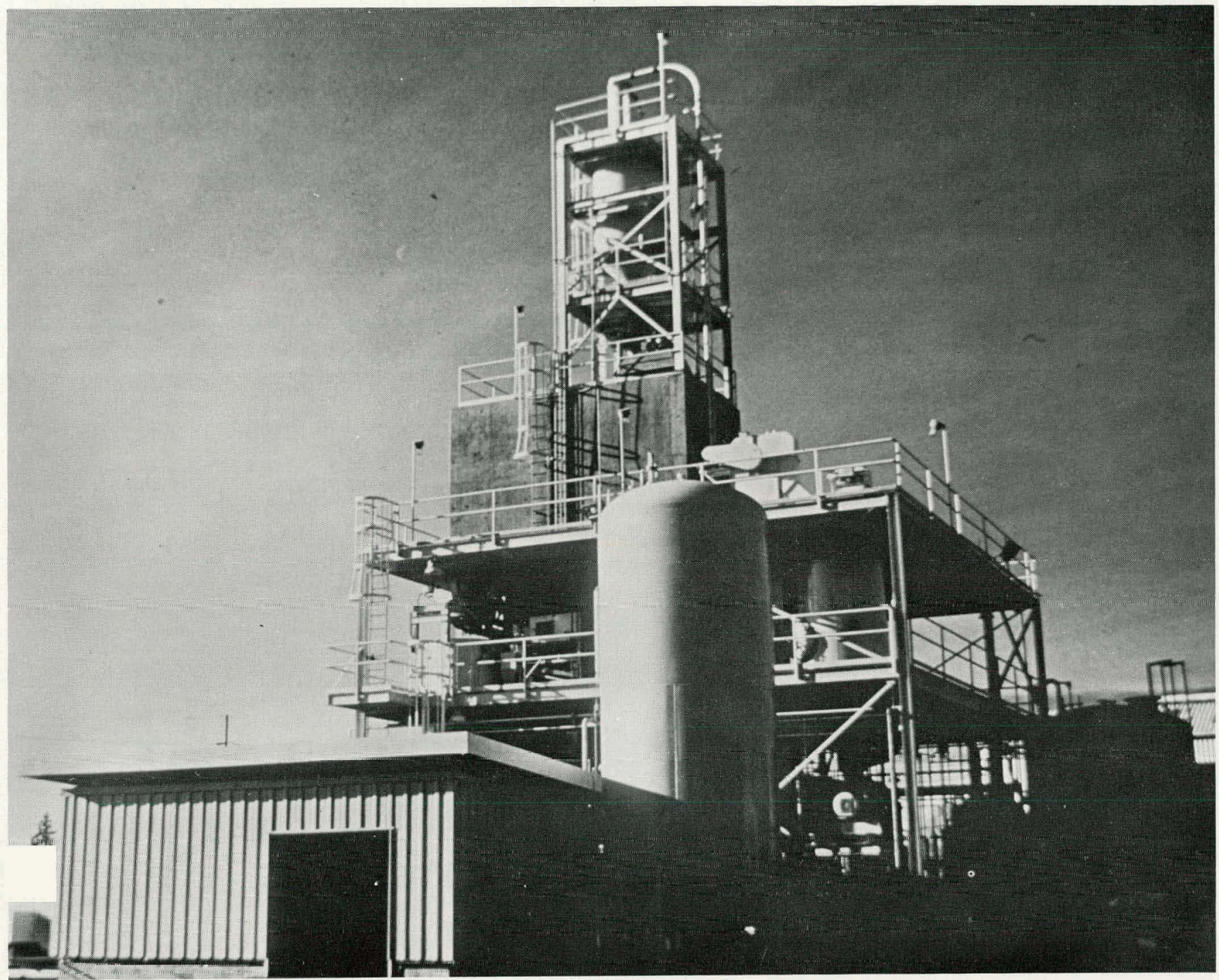

An Albany, Oregon, plant uses biomass. 
- Biomass is safer and cleaner than several other energy sources. Organic waste is typically sulfur-free, and air emissions can be lower in biomass combustion systems than in systems that use some conventional fuels. Furthermore, biomass conversion does not carry the risks of spent fuel disposal or oil tanker spillage.

- It competes economically today in some applications (forest products and food processing) and makes a significant contribution to the national energy budget.

- Certain biomass conversion processes are highly efficient. In most cases, it is more economical to use residues onsite for electricity production even on a small-scale than to transport coal from the mine to the generating plant.

- It is a flexible resource because of its variety of sources, conversion processes, and energy end-products.

- Biomass is ours. We can reduce our dependence on foreign fuel sources and prices over which we have little contrul.

Biomass supplies a small but important part of the total U.S. energy requirement-but it is used today. We have well-developed conversion techniques and an abundant and renewable supply of biomass. Bioenergy can make a significant and valuable contribution to U.S. energy supplies in the very near future. The challenge ahead is to use our resource properly and use it to its fullest potential.

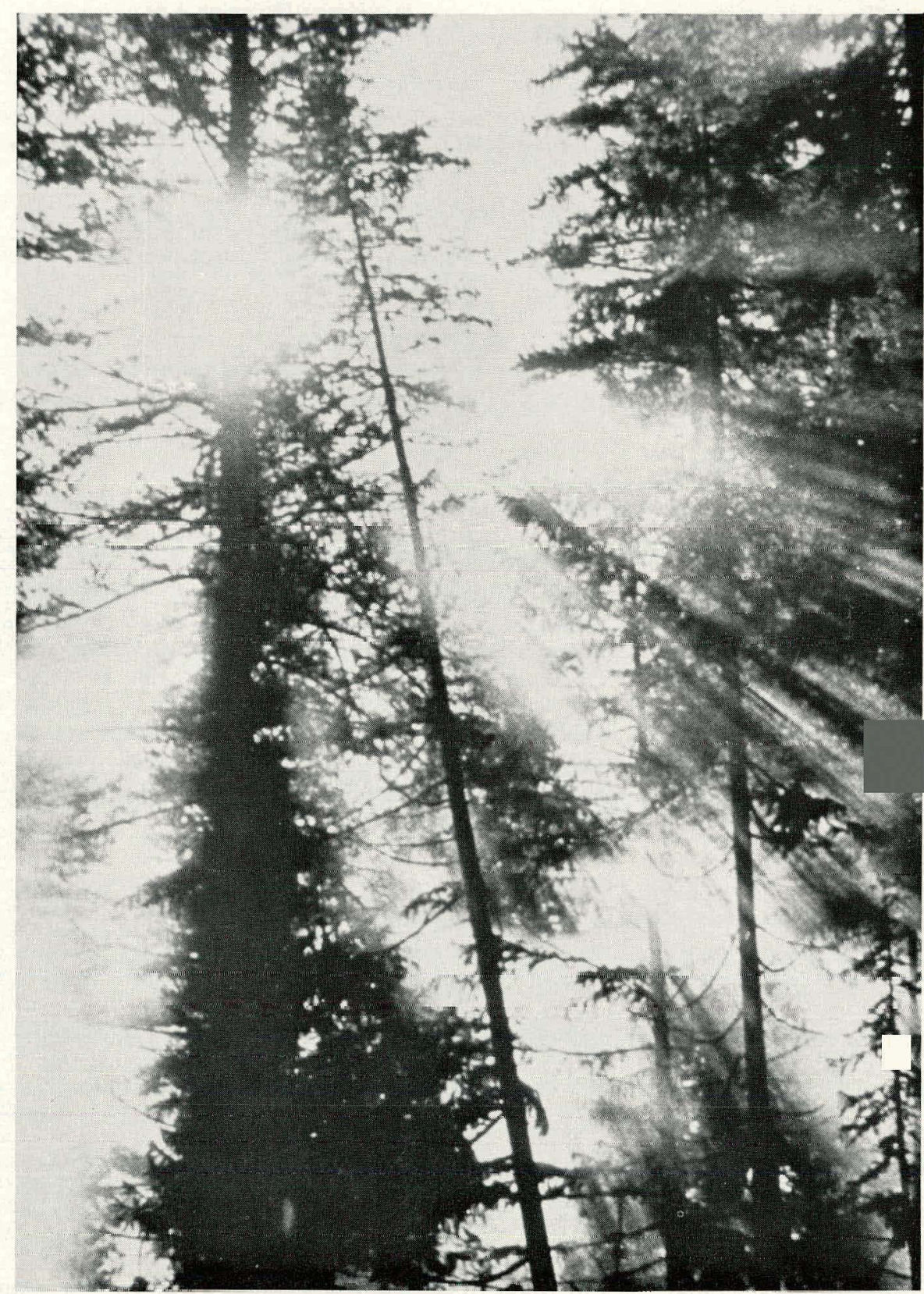

Photo credit: TVA 


\section{For More Information:}

Biofue/s: A Survey, Electric Power Research Institute (EPRI), 3412 Hillview Avenue, Palo Alto, CA 94304, EPRI ER-746-SR, June 1978.

Biomass Energy Success Stories - A Portfolio Illustrating Current Economic Uses of Renewable Biomass Energy, U.S. Department of Energy, HCP/T0285-01, March 1978.

Earl, D.E., Forest Energy and Economic Development, Oxford, England, Clarendon Press, 1975.

Goldsmith, M.W., et al., New Energy Sources: Dreams and Promises, Energy Research Group, Inc., 1661 Worchester Road, Farmingham, MA 01701, 1976.

McVeigh, J.C., Sun Power: An Introduction to the Applications of Solar Energy, Pergamon Press, Inc., Maxwell House, Fairview Park, Elmsford, NY 10523, 1977.

Proceedings: Capturing the Sun Through Bioconversion, March 10-12, 1976, Washington Center for Metropolitan Studies, 1717 Massachusetts Ave., N.W., Washington, DC 20036.

Proceedings: Energy from Biomass and Wastes, August 14-16, 1978, Institute of Gas Technology, 3424 South State Street, Chicago, IL 60616.

Robertson, E.E., Bioconversion Fuels from Biomass, The Franklin Institute Press, Box 2266, Philadelphia, PA 19103, 1977.

Other sources of information include various agencies and associations interested in renewable energy sources. Trade associations such as the Wood Energy Institute, Camden, Maine, and the National Gasohol Commission, Lincoln, Nebraska; state energy offices or extension services; and state solar energy associations are helpful in providing information and referrals.

Some specific sources of reading material and information on biomass are:

The Bio-Energy Council 1625 Eye Street, N.W.

Suite 825A

Washington, DC 20006

Telephone: (202) 833-5656

The Biomass Energy Institute P.O. Box 129 Postal Station C Winnipeg, Manitoba,

Canada R3M 3S7

Mid-American Solar Energy Complex 1256 Trapp Road

Eagan, MN 55121

Telephone: (612) 452-5375

Northeast Solar Energy Center 70 Memorial Drive

Cambridge, MA 12142

Telephone: (617) 661-3500
Southern Solar Energy Center

Exchange Place, Suite 1250

2300 Peachford Road

Atlanta, GA 30338

Telephone: (404) 458-8765

Western SUN

921 S.W. Washington, Suite 400

Portland, OR 97208

Telephone: (503) 241-1222

Technical Information Center

P.O. Box 62.

Oak Ridge, TN 37830

Solar Energy Information Data Bank (SEIDB)

Solar Energy Research Institute 1536 Cole Boulevard

Golden, CO 80401

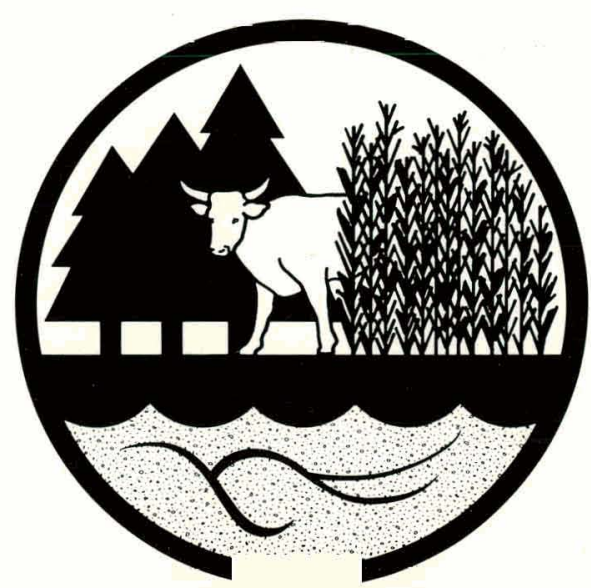




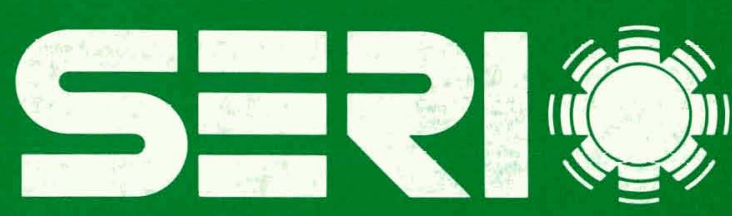

\section{Solar Energy Research Institute}

A Division of Midwest Research Institute

1536 Cole Boulevard

Golden, Colorado 80401

Operated for the under Contract No. EG-77-C-01-4042 